EPiC Series in Language and Linguistics
Volume 2, 2017, Pages 23-35
Professional and Academic Discourse:
an Interdisciplinary Perspective

\title{
From Rote Learning to Motivation: A Cognitive-linguistic Approach to L2 Acquisition of English Idioms by Chinese EFL Learners
}

\author{
Wangmeng Jiang ${ }^{1}$ \\ University of La Rioja, Logroño, Spain \\ wajiang@unirioja.es
}

\begin{abstract}
Idioms are non-compositional expressions where the meaning of the whole is different from the literal meaning of their constituent elements (Cooper, 1999). Because of this special nature, idioms can become a serious "bottleneck" for second language acquisition. In the traditional view, idioms can only be learned through blind memorization, since their meaning is considered arbitrary (e.g. Hamblin \& Gibbs, 1999). By contrast, in cognitive linguistics (CL), idioms are considered to be motivated (Boers, 2004). It is further argued that such cognitive motivation could facilitate the learning of figurative idioms (Kovecses, 2002) and experimental evidence in this respect is gradually accumulating (Boers 2013, 2015).

In this connection, the situation of Chinese learners of English as an L2 has not yet been fully examined. This study aims to fill this research gap through the experimental exploration of the effects of classroom instruction based on cognitive linguistics (CL) on the learning of idioms by Chinese EFL learners. The specific purpose of this study is to verify three hypotheses that involve the short-term and long-term effects of this approach to idiom comprehension and retention and the different effects of metaphor and metonymy. In order to test their validity, an experiment was conducted with fifty Chinese freshmen, including one pre-test, the teaching activity, and two post-tests.

The experiment results provided support for CL-based instruction on English idioms. Both of the two classes perform better after teaching activities, but the experimental group has a higher score and actually acquires more knowledge within the same time limit. In the posttest 2, the experimental group memorized the idioms much better than the control group after two weeks and the difference between the two groups widened to a great extent. Comparing the accuracy rates reveals better short-term and long-term learning for metonymy-based than metaphor-based idioms.
\end{abstract}

\footnotetext{
${ }^{1}$ Financial support for the research on which this paper is based has been provided by the Spanish Ministry of Economy and Competitiveness, grant FFI2013-43593-P.
} 


\section{Research Motivation and Hypotheses}

Idioms are non-compositional expressions where the meaning of the whole is different from the literal meaning of their constituent elements (Cooper, 1999). Because of this special nature, idioms can become a serious "bottleneck" for second language acquisition. For example, for most L2 learners, it is difficult to understand the idiomatic meaning of kick the bucket by analyzing the meanings of its component parts kick, the, and bucket.

In the traditional view, idioms can only be learned through blind memorization, since their meaning is considered arbitrary (cf. the observations in Hamblin \& Gibbs, 1999). By contrast, in cognitive linguistics (CL), idioms are considered to be motivated (Boers, 2004), which is consonant with experimental evidence on the existence of interplay between compositional and idiomatic meaning (cf. Cacciari \& Corradini, 2015). It is further argued that such cognitive motivation could facilitate the learning of figurative idioms (Kövecses, 2002) and experimental evidence in this respect is gradually accumulating (e.g. Boers 2013, 2015). The approach to metaphor and metonymy developed by cognitive linguists provides powerful explanations for how people think and act. Some idioms may combine conceptual metaphor and metonymy. For instance, in the idiom gain the upper hand, the underlying cognitive motivation of hand is the metonymy HAND FOR CONTROL and the word upper is motivated by the conceptual metaphor CONTROL IS UP.

The idiosyncrasy of idioms in Chinese has been addressed by some scholars from a cognitivist perspective (see Zhang \& Bai 2015 and the references therein), and some preliminary experimental work (e.g. Carroll \& Conklin, 2015) points to the difficulties that the non-compositional nature of idioms poses for Chinese speakers of English. However, the situation of Chinese learners of English as an L2 has not yet been fully examined. This presentation aims to fill this research gap through the experimental exploration of the effects of classroom instruction based on cognitive linguistics (CL) on the learning of idioms by Chinese EFL learners. The specific purpose of this study is to verify the following three hypotheses:

Hypothesis 1: $\quad$ Given CL-based instruction, EFL learners can better understand the meanings of idioms and improve their learning outcomes of them.

By presenting the cognitive motivation for idioms, EFL learners can Hypothesis 2: $\quad$ memorize idioms faster and keep them longer in memory.

Hypothesis 3: $\quad$ Since metonymy is a straightforward "afford access” relation, less complex than the pairing of cross-domain correspondences characteristic of metaphor, idioms grounded in metonymy are more easily acquired than those grounded in metaphor.

\section{Methodology}

In order to test the validity of these three hypotheses, an experiment was conducted with fifty Chinese freshmen, including one pre-test, the teaching activity, and two post-tests. Each of the test papers consisted of both subjective questions (e.g. paraphrase) and objective questions (e.g. multiple choice, matching) testing the meaning and form of idioms. The perfect score in each case was 30 . The data of objective items were analyzed quantitatively while open questions were dealt with qualitatively.

The L1 of participants was Mandarin Chinese. One class was randomly chosen as the experimental group with 25 students and the control group consisted in other 25 students.

The teaching activities (see appendix) in the two classes involved the same 30 English idioms whose meanings were extracted from two authoritative idiom dictionaries: The Collins Cobuild Dictionary of 
Idioms (Sinclair \& Moon, 2002) and Oxford Idioms Dictionary for Learners of English (Ashby, 2001).

While the test papers for both groups were the same, different teaching materials were used. Experimental group students were provided with explanations on the conceptual mappings and cognitive motivations underlying idiomatic expressions and their meaning effects. For example, an expression like on top of the world would be explained in terms of the conceptual metaphor HAPPY IS UP. The control group dealt with idioms in the traditional way mainly based on rote learning.

As soon as the teaching finished, both groups were requested to take posttest paper 1, with fill-inthe-gap, completion, and paraphrasing tasks, plus an open-question exercise, which was used to measure the immediate learning effects. After two weeks, posttest 2 (which was based on the same tasks as posttest 1 except for the open questions part since recall effects did not need to be leveled out) was applied to both groups to measure the long-term effect of the different teaching methods. The time limits for teaching and testing in both groups were the same.

After reading the test results, the scores were further prepared in a way that each participant's performance in each question was represented by four kinds of scores: the total scores, the scores for items including metaphors, and the scores for items including metonymies. Scores in the three tests were analyzed by SPSS.

In order to compare the performance in the two classes, independent samples t-tests were conducted. First, a $\mathrm{T}$ test of pretest scores from these two groups was conducted to see if there was any significant difference before the teaching process. Then a $\mathrm{T}$ test of posttest scores was conducted to find out if there was any significant difference after they were taught by different teaching methods.

\section{Results}

\subsection{Results for Hypothesis 1}

\section{Results of Pretest Paper 1 for Both Groups}

\begin{tabular}{|c|c|c|c|c|}
\hline Group & $\mathrm{N}$ & Mean & Std. Deviation & Std. Error \\
\hline Experimental & 25 & 2.86 & 1.903 & .322 \\
\hline Control & 25 & 3.09 & 2.178 & .367 \\
\hline
\end{tabular}

Table 1: Group statistics in pretest paper

\begin{tabular}{|r|c|c|c|c|c|c|}
\hline & \multicolumn{2}{|c|}{$\begin{array}{c}\text { Levene's Test for } \\
\text { Equality of Variances }\end{array}$} & \multicolumn{4}{|c|}{ T-test for equality of means } \\
\cline { 2 - 7 } & $\mathrm{F}$ & $\mathrm{Sig}$ & $\mathrm{t}$ & $\mathrm{df}$ & Sig & $\begin{array}{c}\text { Mean } \\
\text { difference }\end{array}$ \\
\hline $\begin{array}{c}\text { Equal } \\
\text { variance }\end{array}$ & .726 & .398 & -.584 & 68 & .561 & -.233 \\
\hline $\begin{array}{c}\text { Unequ } \\
\text { al } \\
\text { variance }\end{array}$ & & & -.584 & 66.773 & .561 & -.233 \\
\hline
\end{tabular}

Table 2: Independent-samples t-test in pretest paper 
Tables 1 and 2 suggest that the participants had little knowledge of the selected English idioms before the experiment. Table 1 reveals that the 25 participants in the experimental group just obtained a mean of 2.86 points out of a 30-score test, while the other 25 students in the control group had a mean of 3.09. As shown in the outcome of Levene's Test for Equality of Variances, the variances between experimental group and control group do not differ significantly from each other $(\mathrm{p}=0.398)$. This means that it is appropriate for us to adopt the results of the equal variance $t$ test, the result $(p=0.561>0.05)$ of which indicated that the two groups were at the same level in their knowledge of English idioms before the experiment started.

\section{Results of Posttest 1 for Both Groups}

Tables 3 and 4 provide the results of posttest paper 1 for both groups from the outcome of Independent-Samples T test in SPSS.

\begin{tabular}{|c|c|c|c|c|}
\hline Group & $\mathrm{N}$ & Mean & Std. Deviation & Std. Error \\
\hline Experimental & 25 & 25.82 & 11.230 & 1.896 \\
\hline Control & 25 & 17.73 & 14.716 & 2.483 \\
\hline
\end{tabular}

Table 3: Group statistics in posttest paper 1

\begin{tabular}{|c|c|c|c|c|c|c|}
\hline & $\begin{array}{c}\text { Levene's Test for Equality } \\
\text { of Variances }\end{array}$ & \multicolumn{4}{|c|}{ T-test for equality of means } \\
\cline { 2 - 7 } & $\mathrm{F}$ & $\mathrm{Sig}$ & $\mathrm{t}$ & $\mathrm{df}$ & $\mathrm{Sig}$ & $\begin{array}{c}\text { Mean } \\
\text { difference }\end{array}$ \\
\hline $\begin{array}{c}\text { Equal } \\
\text { variance }\end{array}$ & 5.531 & .024 & 2.522 & 68 & .014 & 8.092 \\
\hline $\begin{array}{c}\text { Unequal } \\
\text { variance }\end{array}$ & & & 2.522 & 63.629 & .014 & 8.092 \\
\hline
\end{tabular}

Table 4: Independent-samples t-test in posttest paper 1

The means of both groups in posttest 1 increase dramatically, compared with the low marks in the pretest. The 25 students in the experimental group have a mean of 25.82 points while the mean of the control group is only 17.73. The result of the Levene's Test for Equality of Variance reveals that the variances for the two groups differ significantly from each other, with $\mathrm{p}=0.024<0.05$. After appropriate cognitive-based instruction, the statistics $(\mathrm{p}=0.014<0.05)$ imply that the experimental group performed better than the control group in understanding and memorizing the 30 English idioms, which upholds Hypothesis 1, that is, EFL learners can better understand the meanings of English idioms and further memorize them with the help of cognitive-based instruction.

\section{Results of Ten Additional Idioms in the Posttest Paper 1}

The ten idioms were not included in the teaching material and the test item did not offer any hints on the underlying metaphor or metonymy. Furthermore, the ten idioms were tested on the basis of open questions. For these reasons, the results of the additional idioms in the posttest 1 are described qualitatively rather than being calculated quantitatively. Around half of the students in the experimental group attempted to give the right answers of the figurative meanings of the additional idioms, connected with the previous teaching about CL and the cognitive motivations of idioms. The other half of the 
students in the experimental group ended up with no answers or gave wrong answers. Only 6 students, much less than half of the control group tried hard to come up with the figurative meanings of these new idioms. However, none of them gave the right figurative meanings and the wrong answers were based on literal interpretations. Some wrong answers are illustrated below to reveal the literal misunderstanding of idioms among the learners without cognitive-based instruction.

Example 1 He was foaming at the mouth because of his daughter's behavior.

Right answer: extremely angry

Wrong answers: a bit speechless; feeling thirsty; keeping talking for a long time

Foam at the mouth is based on the metaphors THE MIND IS A CONTAINER and ANGER IS A HOT FLUID IN A CONTAINER. Without teaching the concepts of metaphor, some EFL learners tend to understand new English idioms literally.

Example 2 She'd just discovered she was pregnant and she felt on top of the world.

Right answer: very happy

Wrong answers: dangerous; flying; in the highest position

In this example, the figurative meaning of on top of the world is closely connected with the metaphor HAPPY IS UP. Without the appropriate cognitive-based instruction, students stick to the literal meaning of top and world.

Thus, Hypothesis 1 is further supported by this experiment.

\subsection{Results for Hypothesis 2}

The students in the experimental class learned not only the figurative meanings of the 30 idioms but also the cognitive motivation for each of them. By contrast, the control group only learned the figurative meanings of the 30 idioms. The comparison of tables 1 and 3 shows that both of the two classes perform better after the teaching activities, but the experimental group has actually acquired more knowledge, which suggests that EFL learners can comprehend and memorize English idioms efficiently when given cognitive-based instruction.

In addition, in order to test their long-term memory, posttest 2 was conducted two weeks later and the results are shown in the following tables. Tables 5 and 6 below provide the results of the posttest 2 for the experimental and control groups.

\begin{tabular}{|c|c|c|c|c|}
\hline Group & $\mathrm{N}$ & Mean & Std. Deviation & Std. Error \\
\hline Experimental & 25 & 16.23 & 11.672 & 1.973 \\
\hline Control & 25 & 7.91 & 3.033 & .513 \\
\hline
\end{tabular}

Table 5: Posttest 2 Group Statistics 


\begin{tabular}{|c|c|c|c|c|c|c|}
\hline & \multicolumn{2}{|c|}{$\begin{array}{c}\text { Levene's Test for } \\
\text { Equality of Variances }\end{array}$} & \multicolumn{4}{|c|}{ T-test for equality of means } \\
\cline { 2 - 7 } & $\mathrm{F}$ & $\mathrm{Sig}$ & $\mathrm{t}$ & $\mathrm{df}$ & $\mathrm{Sig}$ & $\begin{array}{c}\text { Mean } \\
\text { difference }\end{array}$ \\
\hline $\begin{array}{c}\text { Equal } \\
\text { variance }\end{array}$ & 35.698 & .008 & 8.984 & 68 & .008 & 18.324 \\
\hline $\begin{array}{c}\text { Unequal } \\
\text { variance }\end{array}$ & & & 8.984 & 38.570 & .008 & 18.324 \\
\hline
\end{tabular}

Table 6: Posttest 2 independent-samples t-test

From Table 5, it could be seen that the means of posttest 2 for both the experimental class and the control class are lower than those of posttest 1 , with 16.23 points and 7.91 points respectively. What is more, the gap between the two classes widens extraordinarily. The $p(0.008)$ in the posttest 2 is much lower than p (0.014) in posttest 1 , meaning that the experimental group has retained the idioms much better than the control group after two weeks, so the differences between the two groups widen. This analysis suggests that cognitive-based instruction has a long-term helpful effect on idiom retention.

\subsection{Results for Hypothesis 3}

\begin{tabular}{|c|c|c|c|c|c|}
\hline & Total score & $\begin{array}{c}\text { Mean in } \\
\text { Posttest 1 }\end{array}$ & $\begin{array}{c}\text { Accuracy } \\
\text { Rate }\end{array}$ & $\begin{array}{c}\text { Mean in } \\
\text { Posttest 2 }\end{array}$ & $\begin{array}{c}\text { Accuracy } \\
\text { Rate }\end{array}$ \\
\hline $\begin{array}{c}\text { Idioms involving } \\
\text { metaphor }\end{array}$ & 15 & 12.16 & $81.07 \%$ & 7.41 & $49.40 \%$ \\
\hline $\begin{array}{c}\text { Idioms involving } \\
\text { metonymy }\end{array}$ & 15 & 13.59 & $90.60 \%$ & 9.06 & $60.40 \%$ \\
\hline
\end{tabular}

Table 7: Accuracy comparison in the experimental group

According to Table 7 , in posttest 1 , the mean of idioms based on metaphor was 12.16 while the mean of idioms based on metonymy is 13.59. In posttest 2, carried out in two weeks later, the mean of idioms based on metaphor drops to 7.41, but the mean of idioms based on metonymy is still higher, with a score of 9.06. By comparing the accuracy rates, it can be found that the outcome of metonymy keeps higher than that of metaphor and the gap widens in the long term. Idioms based on metonymy are better acquired than those based on metaphor, which lends support to Hypothesis 3.

\section{Discussion}

\subsection{The Comparison between Effects of Traditional and Cognitive-based Instruction}

The pretest revealed that the Chinese EFL learners being tested were not good at learning figurative idioms. By contrast, the comparison of the results of the pretest and posttest 1 revealed that the experimental group undergoing instruction based on the cognitivist approach performed better than the control group. In Chinese culture there is little emphasis on self-learning so it is ultimately the quality of the teacher that largely determines students' academic achievement (cf. Wang, 2003:17). This attitude leads to a rather passive way of learning. It also places heavy demands on teachers to improve 
their teaching methods and foster the learning interest of the students.

The traditional teaching method is authoritative to some degree, but it has some shortcomings. It cuts the connections between language and figurative thought, making learning a mechanic process and further reducing the passion for learning. For instance, when teaching a firm hand, the traditional approach is usually to require students to read, take notes and recite its meaning ('strong discipline and control'). While faced with another idiom take sb/sth in hand, students consider it a totally new one and learn it by rote again. This method ignores the close relationship between language and figurative thought which is beneficial for EFL learners to understand idioms. It results in poor efficiency in acquisition. What is more, when confronted with new idioms, their meanings are difficult to deduce from what they have learned before. If the two idioms a firm hand and take sb/sth in hand are taught on the basis of the metonymy HAND FOR CONTROL, the learning effect will be better and more profound. For example, in the additional test in pretest 1, the new idiom get out of hand can be understood easily as 'cannot be controlled'.

According to the results of the present experiment, the cognitive-based teaching method can serve as an important complement because of its emphasis on its underlying thought pattern and its close connection with life experience. As for the 10 additional idioms, about half of the students in the experimental group and most students in the control group could not provide the right answers. This reaffirms the passiveness of Chinese EFL students in the learning process. The fact that the other half in the experimental group gave the right answers suggests that being aware of the cognitive motivation behind idioms can help the students get their more exact meaning. If the students can learn common cognitive motivations and combine them with the context actively, it could be easier for them to recognize the idioms quickly.

\subsection{The Immediate and Long-term Effects of Cognitive-based Instruction}

In the same time span, the experimental group was taught both the idioms and their motivation, while the control group only received instruction on the meanings of idioms. The students' performance revealed that the learning the underlying cognitive motivations of idioms is helpful for EFL learners to comprehend and memorize idioms vividly. By contrast, although the control group had more time to learn the idioms, the students spent more time on rote memorizing, getting half the achievement with twice the effort. The additional test supports another immediate effect of cognitive-based instruction: learners can infer the meanings of new idioms by looking into their common cognitive motivations.

In sum, cognitive-based teaching is (i) more vivid, which assists comprehension and memorization, (ii) more systematic, (iii) interactive, since the students do not simply commit information to memory but ask about it. As a result, this kind of teaching makes learners acquire the idioms with a high level of processing.

\subsection{The Factors Which Influence the Outcome of Cognitive-based Instruction}

The posttest 2 for the two groups reflects some problems. The problems of the experimental group reflected from the test paper include the transfer of mother language and the cultural idiosyncrasy of cognitive motivation.

Some students gave the wrong meaning of the idioms due to the influence of mother language. For instance, the meaning of the idiom make sb's blood boil is 'causing someone to become extremely angry'. But more than half of the students think it means 'being excited', because of the influence of the similar Chinese expression "rè xuè fèi téng" (literally 'hot blood is boiling'), which conveys an idea of excitement rather than anger. It is the Chinese thinking pattern that brings about the misunderstanding 
of some English idioms.

On the basis of the performance in experimental group, it is found that cultural similarities and differences between English and the native language of EFL learners play a critical role in the outcome of cognitive-based instruction. Some English idioms containing metaphors or metonymies with equivalents in Chinese are better learned than those that are different from Chinese. In this experiment, the metaphor BEING HAPPY IS BEING OFF THE GROUND is used similarly in both English and Chinese and hence the related idioms are easier to be acquired. For example, idioms like over the moon, on cloud nine, walk on air and in seventh heaven have higher accuracy in the posttest 1 and posttest 2 conducted in the experimental group. This is due to the fact that the cognitive motivation for the meanings of these four idioms (HAPPY IS UP) is very close to the one for the metaphors in Chinese xìng gāo căi liè (literally 'spirit high appearance strong') and huān hü què yuè (literally 'joyful shout sparrow jump'). The same holds for idioms based on metonymy. Idioms like an old hand and have a head for figures are similar to the metonymies lăo shǒu (literally 'old hand') and yǒu shù xué tóu năo (literally 'have mathematic head brain') in Chinese.

In the posttest paper 2 for the control group, the performance of the students was particularly poor. Most idioms received a blank answer and even when the answers were given, they were similar to those in the pretest (too literal). This situation reflects the serious problems of the traditional teaching method, which acts as the deep reason for the students' poor performance. The first is that traditional mechanical memorizing is not very effective for the long-term retention of idioms. The deep reason may be that the students do not fully understand the meaning of the idiom. That is why the students in the control group could remember the idioms immediately after the teaching activity, but could not remember them after two weeks. The second problem is that the traditional teaching method overemphasizes language form while neglecting the role played by thought. In the test, the students who could not memorize the meaning of an idiom resorted to translating its literal meaning into Chinese. This prevents students from developing effective thinking and reasoning skills that they can apply later to further figurative language learning activities.

\subsection{The Explanation for Different Effects of Metaphor and Metonymy on Idioms Acquisition}

The results of the comparison between the accuracy in the learning of idioms based on metaphor and metonymy in the experimental group show that the retention rate for idioms based on metonymy is higher than for those based on metaphor. The reason can be found in the nature of the cognitive mechanisms involved in metaphor and metonymy. Conceptual metaphor requires the interaction of source and target domains from two discrete conceptual categories. By contrast, in conceptual metonymy the source and target belong to the same domain. It is often the case that people can connect two concepts easily when they belong to the same domain. For example, the product and the producer belong to the 'production' domain. Thus, it is quite easy to understand the sentence I'm reading Shakespeare, with Shakespeare referring to his work. However, the target and source domains of a conceptual metaphor are from two different conceptual categories, thus making it relatively difficult for EFL learners to connect the two domains.

Take let the cat out of the bag in this experiment, for example. The source domain is based on the CONTAINER image schema and the target domain is the MIND. To some degree, the mapping process between the two different domains, MIND and CONTAINER, is a bit complex and time-consuming for an untrained non-native speaker. The meaning of an idiom may not be self-explanatory when the metaphorical motivation varies. Nevertheless, the meaning becomes clearer when the typical thinking patterns associated with a given language are revealed, as in the training provided to the experimental subjects of the present research. There is another possible reason why idioms based on metonymy are learned better than those based on metaphor. As stated in section 3, metaphor makes people link a relatively concrete and perceptually apprehensible domain to an abstract domain, so learners have to 
understand the abstract notion of ANGER by making reference to hot fluids, as in the metaphor ANGER IS A HOT FLUID IN A CONTAINER. However, this is not necessary in the case of metonymy, where idioms directly exploit two concrete items belonging to the same conceptual domain. For example, body part metonymies make use of such notions as HEAD, HAND and EYE, which refer to familiar and frequently-used entities. This makes idioms related to the human body easy to be understood and used. In the results of our analysis, they are learned even quicker than metaphors, probably because they do not involve cross-domain reasoning like the latter.

\section{Conclusion}

On the basis of our experiment and analysis, the three research questions put forward in the beginning have been answered as follows:

(1) The application of cognitive linguistics to second-language idiom teaching and learning can facilitate English idioms acquisition, compared with the traditional method.

(2) Cognitive instruction does have an efficient and long-term effect on idiom acquisition.

(3) The degree of success in the acquisition rates of idioms based on metonymy is higher than that of idioms based on metaphor.

In addition, some further findings are listed below.

1. The students of both the experimental and the control groups are at a low level with regard to their idiom learning before the teaching activities. This situation arises from the lack of emphasis on idiom teaching and learning in China.

2. The outcome of cognitive-based instruction is influenced by the transfer from the mother language, both positively and negatively.

3. The fact that metonymy is based on straightforward source-target connections, while metaphor is not, underlies the more efficient learning of metonymy-based idioms.

To conclude, a cognitive-linguistic approach to the teaching of idioms helped the students in this study by allowing them to achieve more effective results. It also brings freshness into traditional idiom teaching and serves as a good complementary strategy for future idiom teaching and learning.

\section{References} Press.

Ashby, M. (2001). Oxford Idioms Dictionary for Learners of English. Oxford: Oxford University

Boers, F. (2004). 'Expanding learners' vocabulary through metaphor awareness: What expansion, what learners, what vocabulary?’ In Niemeier, S. and M.Achard (Eds.), Cognitive Linguistics, Second Language Acquisition, and Foreign Language Teaching. pp. 211-234. Berlin: Mouton de Gruyter.

Boers, F. (2013). Cognitive Semantic ways of teaching figurative phrases: An assessment. In F. Gonzalvez Garcia, M. S. Pena Cervel, \& L. Perez Hernandez (Eds.), Metaphor and Metonymy Revisited Beyond the Contemporary Theory of Metaphor. pp. 229-263. Amsterdam \& Philadelphia: John Benjamins.

Boers, F., \& Webb, S. (2015). Gauging the semantic transparency of idioms: Do natives and learners see eye to eye? In R. Heredia \& A. Cieslicka (Eds.), Bilingual Figurative Language Processing. pp. 368-392. Cambridge: Cambridge University Press.

Cacciari, C., \& Corradini, P. (2015). Literal analysis and idiom retrieval in ambiguous idioms processing: A reading-time study. Journal of Cognitive Psychology, 27(7), 797-811. 
Carrol, G., \& Conklin, K. (2015). Cross language lexical priming extends to formulaic units: Evidence from eye-tracking suggests that this idea 'has legs'. Bilingualism: Language and Cognition, 1-19.

Cooper, T.C. (1999). Processing of idioms by L2 learners of English. TESOL Quarterly, 33(2), 233262.

Hamblin, J. \& Gibbs, R. (1999). Why you can't kick the bucket as you slowly die: Verbs in idiom comprehension. Journal of Psycholinguistic Research, 28(1), 25-39.

Kövecses, Z. (2002). Metaphor: A Practical Introduction. Oxford: Oxford University Press.

Sinclair, J. \& Moon, R. (Eds). (2002). Collins Cobuild Dictionary of Idioms. Glasgow: Harper Collins.

Wang, X. (2002). Education in China since 1976. Jefferson, North Carolina: McFarland \& Company.

Zhang, D., \& Bai, J. (2015). A cognitive semantic study of idioms from The Book of Songs. In Lu \& Gao (Eds), Chinese Lexical Semantics. Cham: Springer International Publishing, 120-129. 


\section{Appendix}

\section{Teaching material for the experimental group}

(Time limit: 30 minutes)

Understand the notions of metaphor and metonymy first. Then try to memorize the idioms and their meanings, together with their corresponding metaphor or metonymy.

\section{Metaphor (隐喻)}

Metaphor is a set of correspondences (映射) between a source domain (源域) and a target domain ( 目标域). A domain is an internally coherent conceptual characterization. For instance, the following figure describes the conceptual metaphor: LOVE IS A JOURNEY.

Source Domain: JOURNEY

the travelers

the vehicle

the journey

the distance covered

the obstacles encountered

decisions about which way to go

the destination of the journey
Target Domain: LOVE

the lovers

the love relationship itself

events in the relationship

the progress made

the difficulties experienced

choices about what to do

the goal(s) of the relationship

A. Secretiveness

\begin{tabular}{|l|ll|}
\hline \multirow{4}{*}{$\begin{array}{l}\text { MIND IS A CONTAINER; } \\
\text { IDEAS ARE ENTITIES }\end{array}$} & $\mathbf{1 .}$ & $\begin{array}{l}\text { spill the beans } \\
\text { to tell people secret information }\end{array}$ \\
\cline { 2 - 3 } & $\mathbf{2 .}$ & $\begin{array}{l}\text { lift/blow the lid off sth } \\
\text { to reveal the true nature which has previously been hidden }\end{array}$ \\
\cline { 2 - 3 } & 3. & $\begin{array}{l}\text { hold your tongue } \\
\text { to remain silent although you would like to give your opinion }\end{array}$ \\
\cline { 2 - 3 } & $\mathbf{4 .}$ & $\begin{array}{l}\text { let the cat out of the bag } \\
\text { to tell people secret information, often without intending to }\end{array}$ \\
\hline
\end{tabular}

B. Anger

\begin{tabular}{|l|ll|}
\hline \begin{tabular}{l} 
MIND IS A CONTAINER; $\begin{array}{l}\text { ANGER IS A HOT FLUID } \\
\text { IN A CONTAINER }\end{array}$ \\
\hline
\end{tabular} & 5. & $\begin{array}{l}\text { make sb's blood boil } \\
\text { to make someone very angry }\end{array}$ \\
\hline & 6. & $\begin{array}{l}\text { hit the ceiling } \\
\text { to become very angry and start shouting }\end{array}$ \\
\cline { 2 - 3 } & $\begin{array}{ll}\text { get steamed up } \\
\text { to become very angry or excited }\end{array}$ \\
\cline { 2 - 3 } & $\begin{array}{l}\text { flip your lid } \\
\text { [1] informal to suddenly become very angry [2] humorous to } \\
\text { go mad }\end{array}$ \\
\hline
\end{tabular}

C. Happiness 


\begin{tabular}{|c|c|}
\hline \multirow{4}{*}{$\begin{array}{l}\text { BEING HAPPY IS BEING } \\
\text { OFF THE GROUND }\end{array}$} & $\begin{array}{ll}\text { 9. } & \text { on cloud nine } \\
\text { extremely happy }\end{array}$ \\
\hline & $\begin{array}{l}\text { 10. over the moon } \\
\text { very happy and excited }\end{array}$ \\
\hline & $\begin{array}{l}\text { 11. in the seventh heaven } \\
\text { in a extremely happy situation }\end{array}$ \\
\hline & $\begin{array}{l}\text { 12. float/ walk on air } \\
\text { to be very happy and excited because something very pleasant } \\
\text { has happened to you }\end{array}$ \\
\hline
\end{tabular}

D. Love

\begin{tabular}{|c|c|}
\hline \multirow{3}{*}{ LOVE IS FIRE } & $\begin{array}{l}\text { 13. an old flame } \\
\text { a person who you had a romantic relationship with in the past }\end{array}$ \\
\hline & $\begin{array}{l}\text { 14. carry a torch } \\
\text { to secretly love someone who does not love you }\end{array}$ \\
\hline & $\begin{array}{l}\text { 15. have the hots for sb } \\
\text { to be strongly sexually attracted to someone }\end{array}$ \\
\hline
\end{tabular}

\section{Metonymy ( 转喻)}

In regard to metonymy, there is also transference from one domain to the other one but they are closely associated or the same. For example, an instrument is closely related to the action in which it is used (INSTRUMENT FOR ACTION), a part is closely related to the whole (A PART FOR THE WHOLE).

\section{A. Idioms related to the hand}

\begin{tabular}{|c|c|}
\hline $\begin{array}{l}\text { THE HAND STANDS FOR } \\
\text { THE PERSON }\end{array}$ & $\begin{array}{l}\text { 1. an old hand } \\
\text { someone who has done a particular job or activity for a long time } \\
\text { and who can do it very well }\end{array}$ \\
\hline \multirow{2}{*}{$\begin{array}{l}\text { THE HAND STANDS FOR } \\
\text { THE ACTIVITY }\end{array}$} & $\begin{array}{l}\text { 2. keep your hands clean } \\
\text { to avoid becoming involved in any activities which are bad or } \\
\text { illegal }\end{array}$ \\
\hline & $\begin{array}{l}\text { 3. give sb a big hand } \\
\text { to clap our hands loudly and enthusiastically }\end{array}$ \\
\hline \multirow{2}{*}{$\begin{array}{l}\text { THE HAND STANDS FOR } \\
\text { CONTROL }\end{array}$} & $\begin{array}{l}\text { hand } \\
\text { iscipline and control }\end{array}$ \\
\hline & $\begin{array}{l}\text { 5. take sb/sth in hand } \\
\text { to take control of someone or something, in order to improve } \\
\text { them }\end{array}$ \\
\hline
\end{tabular}

B. Idioms related to the head

\begin{tabular}{|l|ll|}
\hline $\begin{array}{l}\text { THE HEAD STANDS FOR } \\
\text { THE PERSON }\end{array}$ & $\begin{array}{l}\text { 6. } \\
\text { two heads are better than one } \\
\text { two people who are trying to solve a problem together achieve } \\
\text { more than one person who works alone }\end{array}$ \\
\hline $\begin{array}{l}\text { THE HEAD STANDS FOR } \\
\text { REASON }\end{array}$ & $\begin{array}{l}\text { keep your head } \\
\text { to remain calm, especially in difficult or dangerous situation }\end{array}$ \\
\cline { 2 - 2 } & $\begin{array}{l}\text { out of/off one's head } \\
\text { [1] crazy [2] not knowing what you are doing because of the } \\
\text { effects of alcohol or drugs }\end{array}$ \\
\hline
\end{tabular}




\begin{tabular}{|c|c|}
\hline $\begin{array}{l}\text { THE HEAD STANDS FOR } \\
\text { INTELLIGENCE }\end{array}$ & $\begin{array}{l}\text { 9. have a head for figures } \\
\text { to be good at doing sums }\end{array}$ \\
\hline $\begin{array}{l}\text { THE HEAD STANDS FOR } \\
\text { COMPREHENSION }\end{array}$ & $\begin{array}{l}\text { 10. above/over sb's head } \\
\text { too difficult for sb to understand }\end{array}$ \\
\hline
\end{tabular}

C. Idioms related to the eyes

\begin{tabular}{|c|c|}
\hline \multirow{2}{*}{$\begin{array}{l}\text { THE EYE STANDS FOR } \\
\text { ATTENTION }\end{array}$} & $\begin{array}{l}\text { 11. catch sb's eye } \\
\text { to attract sb's attention }\end{array}$ \\
\hline & $\begin{array}{l}\text { 12. take your eye off the ball } \\
\text { to stop paying attention for a moment to something they are doing }\end{array}$ \\
\hline \multirow{3}{*}{$\begin{array}{l}\text { LOOKING AT } \\
\text { SOMETHING STANDS } \\
\text { FOR DESIRING IT }\end{array}$} & $\begin{array}{l}\text { 13. be all eyes } \\
\text { to watch something or someone with a lot of interest }\end{array}$ \\
\hline & $\begin{array}{l}\text { 14. with an eye to (doing) sth } \\
\text { intending to do sth }\end{array}$ \\
\hline & $\begin{array}{l}\text { 15. have your eye on sth } \\
\text { to have seen something that you want and that you intend to get }\end{array}$ \\
\hline
\end{tabular}

